systern in hypocotyls (Aust. J. Bot., 8, 1; 1960). Buds were induced on portions of epidermal tissue grafted in inverted positions on hypocotyls, and on hypocotyls subjected to reversal of the direction of gravity and electric polarity normally acting on them. The effects of experimental incisions into adventitious meristems, and in close proximity to them, were also studied. The basic pattern of development remained constant under all trcatments. These experiments show that the epidermal and cortical colls from which the adventitious buds and their dependent vascular traces develop possess a very strong inherent polarity which could not be varied by extracellular changes of fiold.

\section{Roosting Preferences of a Whiskered Bat}

Investigations by Lord Cranbrook, and outlined in a recent issue of the Transactions of the Suffolk Naturalists Society (2, Part 4), have shown that a whiskered bat, given the opportunity of roosting in a vertical crevice, a horizontal crevice, a bare wall or hanging freely from the roof, showed a strong preference for the first. In a crevice of varying widths, it chose a place where the tips of the hairs on its back just touched the surface behind it, and it did not appear to mind whether it roosted in darkness or light; touch seemed to be the deciding factor.

\section{Popular Culture and Personal Responsibility}

ThF National Union of Teachers is organizing a conference entitled "Popular Culture and Personal Responsibility", which is to be held at Church House, Westminster, London, S.W.1, during October 26-28. The conference has been divided into eight sessions, including such topies as the growth of communications in modern society, moral and cultural standards, the effects of mass media (with particular reference to young people), how the mass media are being used, the responsibility of the provider, the restrictions of working in the media, and the approach and attitude to the mass media. Further information can be obtained from the Public Relations Department, National Union of Teachers, Hamilton House, Mabledon Place, London, W.C.1.

\section{University News :}

London

DR. J. S. Rowlinson, senior lecturer in the University of Manchester, has been appointed to the University chair of chemical technology tenable at the Imperial College of Science and Technology.

Among those appointed to readerships are: Dr. R. J. Goldacre (cell physiology), tenable at the Institute of Cancer Research, Royal Cancer Hospital; Mr. M. J. Way, at present principal scientific officer at Rothamsted Fxperimental Station (applied entomology), tenable at the Imperial College of Science and Technology.

\section{College of Aeronautics, Cranfield}

Among the recent appointments to lectureships at the College of Aeronautics are Mr. A. Rothwell (aircraft design) and Dr. A. C. Smith (mathematics).

\section{Announcements}

Mr. H. Stanfsby has been appointed deputy director of research at the General Post Office. He is at present staff engineer in the Radio Planning and
Provision Branch of the General Post Office Engineering Dopartment. Mr. Stanesby has been closely connected with the work of the Institution of Electrical Engineers, and was chairman of the Radio and Telecommunications Section in $1955-56$. In 1953 he was awarded the Insignia Award for Technology of the City and Guilds of London for his work in telecommunications.

DR. D. C. Garrate has been elected chairman of the British I'harmaceutical Conference for 1960-61 and will preside at the meeting of the Conference to be held in Portsmouth during the week beginning September 18, 1961. Dr. Garratt is chief analyst to Boots Pure Drug Co., Ltd., Nottingham; he is also a vice-president of the council of the Socioty for Analytical Chemistry, and is chairman of its Analytical Methods Committce.

Tre Palæontographical Socicty has appointed Messrs. Bailey Bros. and Swinfen as distributing agents for its publications; inquiries about these publications should be sent to Bailey Bros. and Swinfen, Ltd., Hyde House, West Central Street, London, W.C.1.

THE Department of Chemical Technology of the Bradford Institute of Technology is holding a special short course on "Recent Developments in Plastics and Polymer Chemistry" during October 28-29. Further information can be obtained from Dr. W. R. Moore, Department of Chemical Technology, Bradford Institute of Technology, Bradford, 7. The

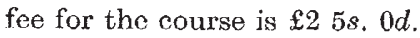

The American Association for the Advancement of Science will sponsor a symposium on the Sciences in Communist China during its annual meeting in New York City on December 26-27, under a grant from the National Scionee Foundation. Preliminary plans call for reviow papers delivered by eminent American and international specialists on Communist China. Publication of these papers as a monograph is contemplated for the spring of 1961 .

Prof. A. R. Urbelohde (Imperial College of Science and Technology) will deliver the fifth Charles Tennant Memorial Lecture entitled "Melting and Freezing" in the Royal College of Science and Technology, George Street, Glasgow, on November 4. Further information can be obtained from the Society of Chemical Industry, 14 Belgrave Square, London, S.W.1.

THE sixth congress on Theoretical and Applied Mechanics and a symposium on High Speed Computation Methods and Machines are being organized by the Indian Society of Theoretical and Applied Mechanics at the University of Delhi during Decem. ber 23-26. The symposium is being jointly sponsored with the IBM International. Persons wishing to be present at either or both functions should contact. Dr. B. R. Seth, Indian Institute of Technology, Kharagpur, India, from whom further information can also be obtained.

ERRATA. In the article entitled "Evolution of Nuclear Power Plant Design", by Sir Christopher Hinton, in Nature of September 24, on p. 1065, col. 2, line 13 , the size of uranium rods is wrongly given as $17 \mathrm{in.}$ in diameter; this should be 1 in.; on p. 1067, col. 2, par, 3, lino 5, for "reaction" read "reactor". 